\title{
Shocking Waves at the Museum: The Bini-Cerletti Electro-shock Apparatus
}

\author{
ALESSANDRO ARUTA* \\ Keywords: Electroshock Apparatus; Electroconvulsive Therapy; Exhi- \\ bition; Scientific Museology; Lucio Bini; Ugo Cerletti
}

The historian of science, Lorraine Daston, has written about things that talk. ${ }^{1}$ But how much can an artefact in a museum communicate its history to the public? Artefacts in museums speak, but it is not necessarily, or even at all, in the language of their original time and place. Cultural baggage, memories, and imagination all come into play, including those held by museum curators, and not least those contained within the operational and historical frameworks of such institutions. ${ }^{2}$ At the Museo di Storia della Medicina della Sapienza at the University of Rome we are organising an exhibition around an artefact that more than any other elicits emotive reactions - the Bini-Cerletti apparatus for the administration of electro-shock. ${ }^{3}$ This prototype of the first ECT machine, along with various historical documents, manuals, and textbooks relating to it, is a valued part of the Museo's collection. We are proud of it, yet as a display item, it is also something of golden chalice. Leaving aside the ethical question of whether we can (or should) convey to visitors the anxiety and pain of the patients who once submitted to the device, and leaving aside the different loads of historical and contemporary baggage that visitors will bring to it, how can such an object be represented in an historically honest way? This is the problem, for while we might be true to the context of its emergence, within

(C) Alessandro Aruta, 2011.

*Alessandro Aruta, Museo di Storia della Medicina, Sapienza Università di Roma, Viale dell'Università, 34/A - 00185, Rome, Italy. Email: alessandro. aruta@uniroma1.it

\footnotetext{
${ }^{1}$ Lorraine Daston, Things that Talk: Object Lesson from Art and Science (New York: Zone Books/MIT Press, 2004). For new and interesting ways to stimulate the interest of the visitors to scientific museums see Jorge Wagensberg Lubinski, The Intellectual Joy in Science Museums, presentation at the IX Antonio Ruberti Lecture, Conference Room, CNR Headquarters, Rome, 8 November 2010. For many of the problems, see Bettina Messias Carbonell (ed.), Museum Studies: An Anthology of Contexts (Oxford: Blackwell, 2004), especially Part IV: 'Locating History in the Museum'.
}

\footnotetext{
${ }^{2}$ This point has been well made in Claudia Stein and Roger Cooter, 'Visual Objects and Universal Meanings: AIDS Posters and the Politics of Globalisation and History', Medical History, 55 (2011), 85-115.

${ }^{3}$ The Bini-Cerletti electro-shock apparatus is one of the best examples of a museum object understood as semioforo, that is, a vehicle of meanings, histories, scientific controversies, but, even before, of doubts and emotions. In fact, as Ulrich Tröhler has remarked with regard to the collection of gynaecological instruments in Göttingen, it gives us no information about what was thought, what was felt, what was done: Ulrich Tröhler, 'Tracing Emotions, Concepts and Realities in History: The Göttingen Collection of Perinatal Medicine', in Non-Verbal Communication in Science Prior to 1900 (Firenze: Olschki, 1993).
} 


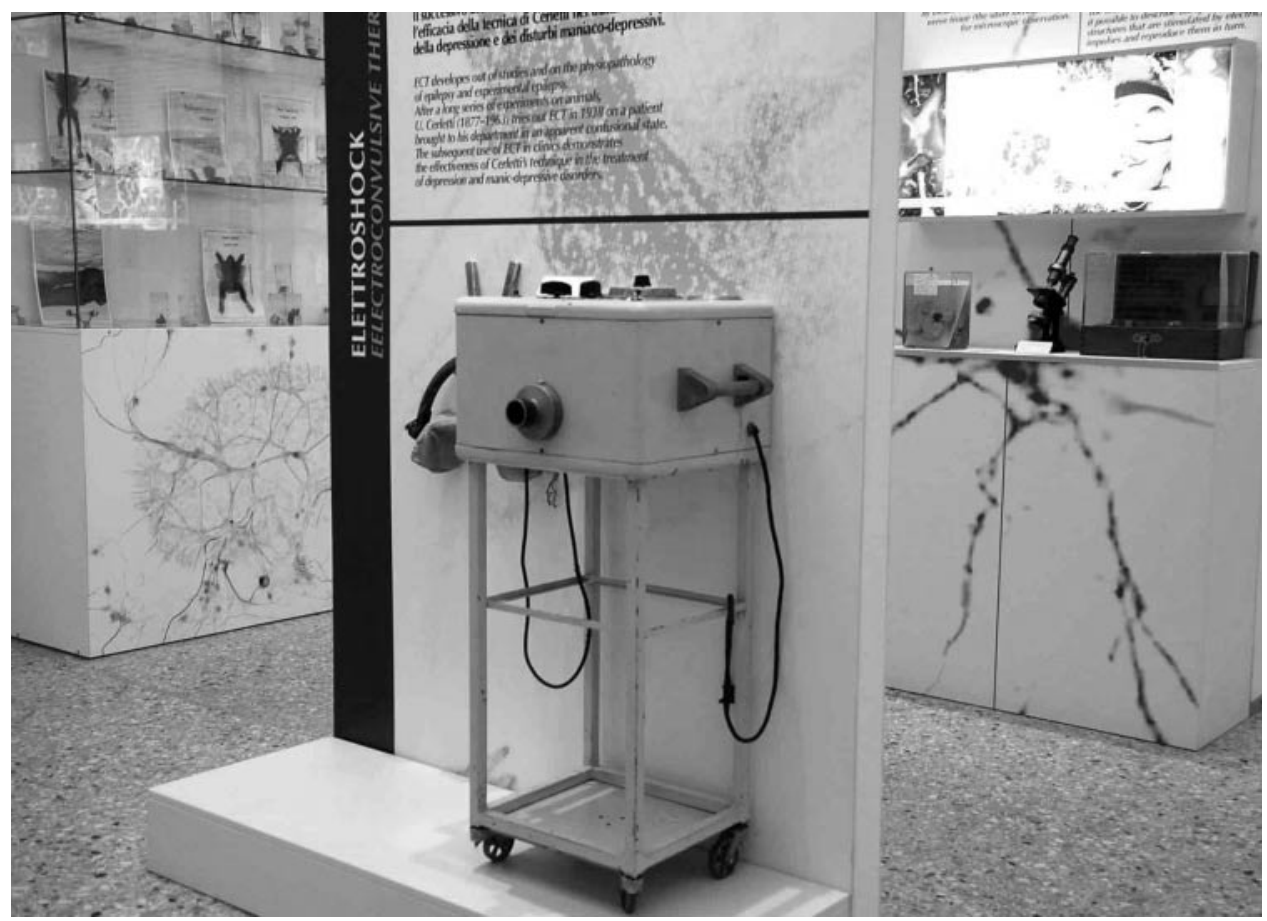

Figure 1: Prototype of the electroshock machine, Museum of History of Medicine. Courtesy of Sapienza University, Rome.

that context (of Fascist Italy) the Bini-Cerletti apparatus was at one and the same time a blessing, a hope, a lie, and a profitable commercial product.

Named after the Italian psychiatrist and neurologist Ugo Cerletti (1867-1963) and his student Lucio Bini (1908-64), the apparatus was a therapeutic advance when it arrived on the scene in April 1938. Before then - though only since 1933 - there was insulin therapy, devised by Manfred J. Sakel (1900-57). But insulin therapy bore the high risk of irreversible neurological damage as well as terminal coma. There were also - though again only recently - formative attempts at the chemotherapeutic treatment of psychic disorders, such as the Cardiazol therapy proposed in 1935 by Joseph L. von Meduna (1896-1964). Last but not least, there was prefrontal leucotomy, introduced in 1936 by Antonio E. Moniz (1874-1955) and renamed 'lobotomy' a few years later by Walter Freeman. Radical, dramatic, and irreversible, lobotomy was also an expensive procedure. ${ }^{4}$ It was in the face of these alternatives that Cerletti came up with ECT, specifically as therapy for schizophrenia.

\footnotetext{
${ }^{4}$ See Riassunto di una Comunicazione del prof. $U$. Cerletti e del dott. L. Bini alla R. Accademia Medica di Roma il 28 maggio 1938 - XVI);

Ferdinando Accornero, 'Testimonianza oculare sulla scoperta dell'elettroshock', in Pagine di storia della medicina, 14, 2 (1970), 39-49; Gilberto Corbellini,
}

'L'epilessia nella neurologia clinica e sperimentale del Novecento', in Experimentum Naturae: Saggi sull'Epilessia (Udine: Casamassima, 1992), 138-3; Roberta Passione, Il Romanzo dell' elettroshock (Reggio Emilia: Aliberti, 2007), 68-9. 
Ugo Cerletti was educated at Rome University, and shared with the Roman school of psychiatry the idea of welding psychiatric research to new knowledge from the microscopic study of tissues. Applied to the brain and nervous system, this was a means to comprehend the organic causes of mental disease and, hence, surpass the vague concept of 'degeneration'. After studying under Giovanni Mingazzini (1859-1929), 'the best anatomist of the nervous system in Italy', ${ }^{6}$ Cerletti worked with Camillo Golgi (1843-1926) who, having found a way to selectively colour nerve cells, was able to refine the investigation of cases of mental disease that did not reveal significant damage through autopsy. Golgi's own studies were furthered in Heidelberg in 1899, where Cerletti was also to study and come into contact with Franz Nissl (1860-1919), the world-famous neuropathologist and neuro-anatomist whose method greatly refined cellular staining techniques. ${ }^{7}$ Neurology, Cerletti came to believe, must move beyond the anatomy table. But at the same time as he pursued Golgi and Nissl's techniques in Germany at the turn of the century, he came into contact with Gestalt psychology, as well as holistic notions of the nervous system. These were to be fundamental components in his further research, leading to his opinion in the 1920s that it was impossible to link specified areas of the brain to psychic functions. There are, he concluded, mental diseases whose origins cannot be related to anatomico-pathological data.

Cerletti wanted to integrate his results from histopathology with the biological study of emotions, adopting a global and interdisciplinary approach. It was in this context that the electro-shock apparatus first appeared. Built by Bini under Cerletti's instruction, it was meant to be a tool for research and inquiry, not the instrument it would become for 'simple and practical' therapy and artificially induced 'therapeutical epilepsy'. It was in April 1938, on the first floor of a laboratory of the the Clinica delle Malattie Nervose e Mentali della Regia Università di Roma [Rome Royal University Clinic for Nervous and Mental Illnesses], that it was first tried out in terms of what would later be hailed as 'the reaction of the nervous system to guarantee the survival and the proper regulation of instincts and the balanced answer of the organism to external solicitations. ${ }^{8}$ An eyewitness account by Ferdinando Accornero, one of the many students observing the trial, relates that the machine stood on a table, between entangled rows and electrical devices. The patient was a schizophrenic taken to hospital by the police some weeks before, after having been found wandering through the streets of Rome. He was able to communicate only through a self-made slang, and presented no signs of any emotional feeling. Now passive, and with his head shaven, the patient lay

\footnotetext{
${ }^{5}$ Roberta Passione, 'Non solo l'elettroshock: Ugo Cerletti e il rinnovamento della Psichiatria italiana', in Marco Piccolino (ed.), Neuroscienze Controverse: Da Aristotele alla moderna scienza del linguaggio (Torino: Bollati Boringhieri, 2008), 258. The changes that took place in Italian psychiatry in the first half of the twentieth century relied on developments of the late nineteenth century, especially at the centres in Reggio Emilia, Naples and Rome, where the key figures were, respectively, Augusto Tamburini
}

(1848-1919), Leonardo Bianchi (1848-1927) and Ezio Sciamanna (1850-1905).

${ }^{6}$ Ibid., 258.

${ }^{7}$ Luciano Mecacci and Alberto Zani, Teorie del cervello: Dall'Ottocento a oggi (Torino: Loescher, 1982); Carmela Morabito, La mente nel cervello: Un'introduzione storica alla neuropsicologia cognitiva (Rome: Laterza, 2004).

${ }^{8}$ Passione, op. cit. (note 5), 270. 


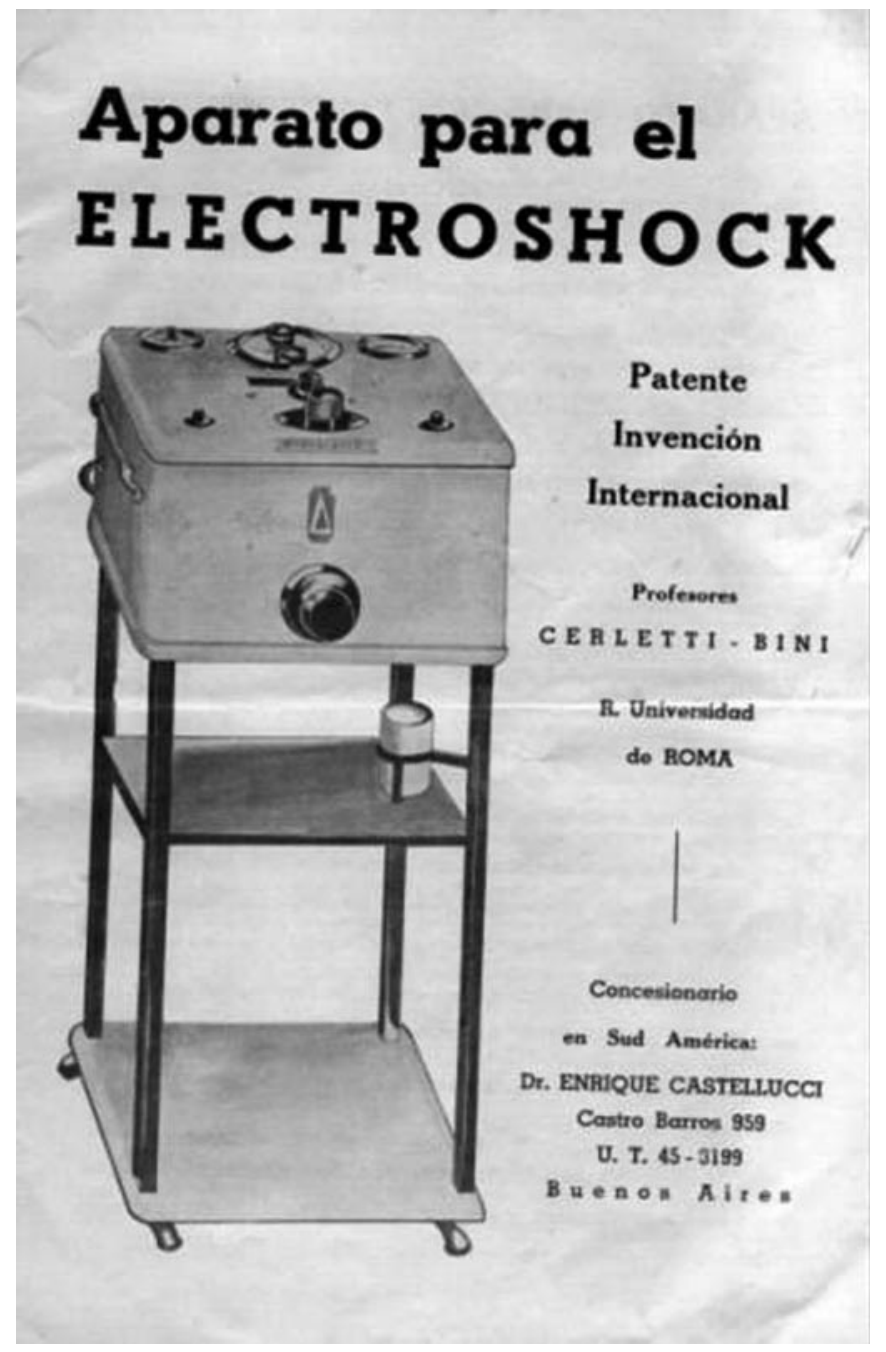

Figure 2: Patent of the electroshock machine, Archive of the Museum of History of Medicine. Courtesy of Sapienza University, Rome.

on a bed and had two electrodes attached to his temples. He was provided with a gauzewrapped gum pipe to bite on. After some seconds of silence and uncertainty, followed by the patient shouting to Cerletti not to administer him the 'deadly' shake (suggesting that the patient somehow already knew the horrors of the thing), the order was given and the button pressed. Convulsion. After the treatment, the patient began to be interested in his surroundings; he became clear-headed and appeared in good health. ${ }^{9}$

${ }^{9}$ Accornero, op. cit. (note 4), author's translation. 


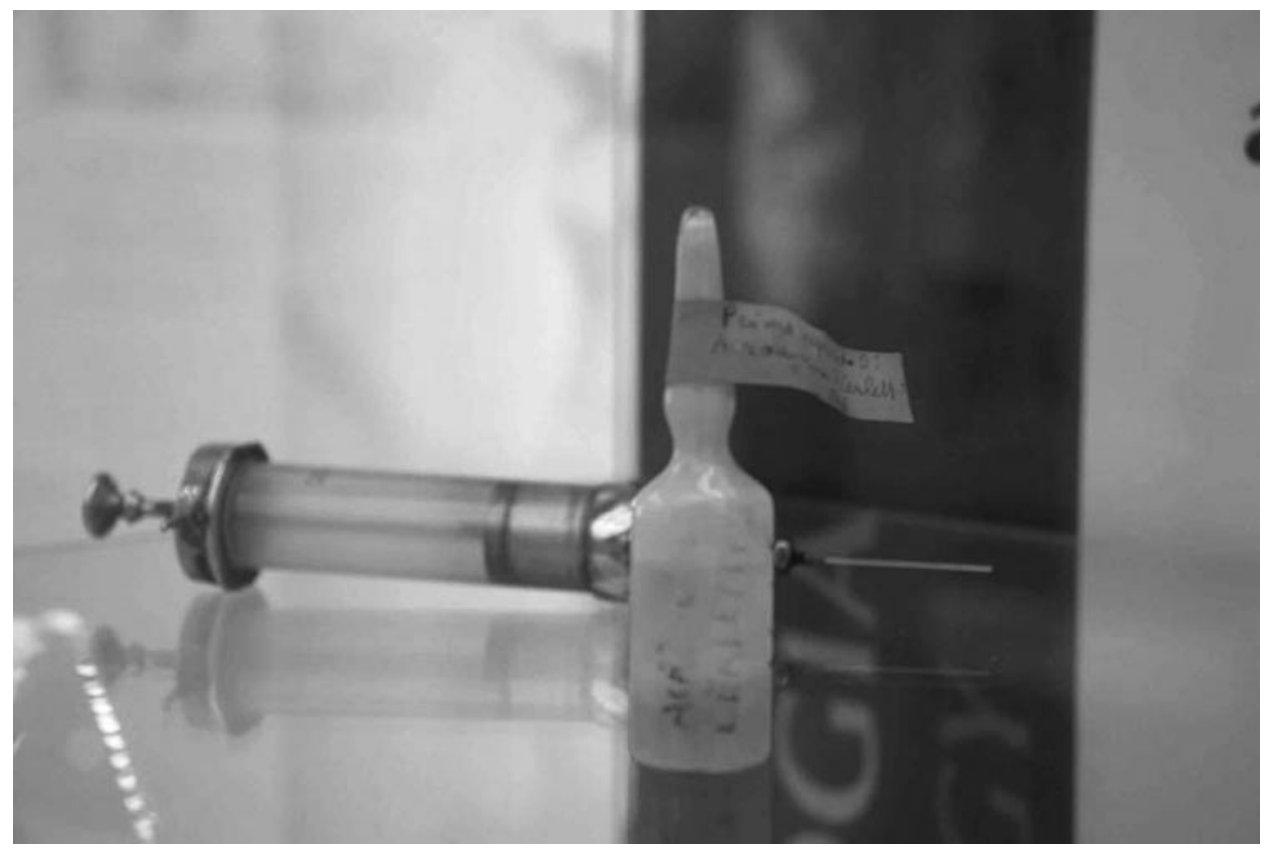

Figure 3: Acroagonine vial, Museum of History of Medicine. Courtesy of Sapienza University, Rome.

\section{Or did he? According to Accornero:}

[N]ot only did we want to prove that it was possible to create an epileptic seizure by means of electricity; most of all, we wanted to show that such an attack had a therapeutic value not different from the one created by the intravenous [insulin] injection of Cardiazol. We thus needed a patient affected by a definitive psychopathy - and we got one. Should our endeavour be successful, medicine would have gained a new and efficient weapon against madness. ${ }^{10}$

Thus, the experiment was presented as a scientific success, the result of preserving clinicians overcoming uncertainty. According to Roberta Passione, who has made a study of Lucio Bini's notebooks, the events outlined above are entirely fictional. They constitute an 'electro-shock novel' which was authored by the self-celebrating Cerletti through the control he exercised over what his students could report. It is a self-fashioned heroic science narrative 'that crosses the border of myth'. ${ }^{11}$ Omitted is that there had been at least three failed attempts prior to the one described above, each one with a correspondingly higher voltage before the desired result was achieved. No wonder the patient knew what was coming! Moreover, it was not until some two months later, at a public conference, that Cerletti began to brag that 'we can cause an epileptic seizure in man without danger, by using electricity.',

${ }^{10}$ Ibid., 45.

${ }^{11}$ Passione, op. cit. (note 4), 76.

${ }^{12}$ Accornero, op. cit. (note 4), 48. author's translation. The new therapy was officially introduced to the scientific community on 28 May 1938, at the R. Accademia Medica in Rome. See Riassunto, op cit. (note 4). 


\section{Alessandro Aruta}

Experiments with the Bini-Cerletti electroshock apparatus continued, as much for the perfection of the machine as for the therapy. It was also patented (by Bini, according to documents in our museum) and exported around the world. ${ }^{13}$ It became a source of considerable economic gain, even though both Bini and Cerletti were critical of colleagues (especially American) who regarded the device as a source of profit. Various models were developed and successfully marketed, such as the portable one that the Museo also holds. Nor did its commercial potential stop there, at least indirectly; in 1947, through experiments on pigs, Cerletti extracted emulsions released by the brain under electroshock (what he called 'acroagonines'), and he constructed a hypothesis about their brain-curing properties. ${ }^{14}$ The interest in this was such that the industrial production of acroagonines was taken up by pharmaceutical companies in South America, although apparently without Cerletti's authorisation. ${ }^{15}$

Like all artefacts in museums, then, the Bini-Cerletti electro-shock apparatus conceals a great deal of history. It 'talks', but in languages not always easy, or simultaneously, to convey to visitors to the Museo - visitors who also know that present-day versions of the machine continue to operate on 'consenting' patients. It is far easier for them to emotionally interact with the idea of it, deciding whether or not themselves to push the on/off button.

\footnotetext{
${ }^{13}$ All the patents and franchises for the sale of the apparatus can be viewed at the archive of the Museo di Storia della Medicina [Museum of History of Medicine], Sapienza University of Rome.
}

\footnotetext{
${ }^{14}$ See Stefano Canali, 'Il Comitato Nazionale di Consulenza per la Biologia e la Medicina', in Per una storia del CNR, Vol. II (Bari: Laterza, 2001), 17-18.

${ }^{15}$ Passione, op. cit. (note 5), 274-7.
} 